\title{
Effect of Protaetia brevitarsis seulensis larvae fermented by Bacillus subtilis on serum lipid contents and liver morphology in orotic acid-induced fatty-liver model Sprague-Dawley rats
}

\author{
So-Yeon Sim, Hee-Young Ahn, Young-Su Cho* \\ *Department of Biotechnology, Dong-A University, Busan 49315, Korea
}

\section{Bacillus subtilis를 이용한 발효 굼벵이가 비알코올성 유발 지방간 흰쥐의 혈중 지질 및 간 조직의 morphology에 미치는 영향}

\author{
심소연 · 안희영 · 조영수* \\ *동아대학교 생명공학과
}

\begin{abstract}
We investigated the effect of Protaetia brevitarsis seulensis larvae fermented by Bacillus subtilis (FPb) on the orotic-acid-induced fatty livers of Sprague-Dawley (SD) rats. FPb was found to reduce SD-rat organ size and serum triglyceride levels. Conversely, serum lipid levels were elevated to normal levels, which helped to improve the liver. Total lipid and free fatty acid levels in the serum were lower in the group fed with FPb than in the group fed with Protaetia brevitarsis seulensis larvae (NPb) and showed an overall improvement in lipid metabolism. In a similar manner, the FPb group exhibited an HDL-cholesterol content that was similar to the normal group fed with NPb compared to the group fed only with orotic acid. On the other hand, the group administered with a high concentration of FPb exhibited intracellular toxicity. Pathological observations of liver tissue also revealed that hepatic lobular liver cells were uniformly arranged in the group fed with FPb powder, thereby improving the fatty liver. Protaetia brevitarsis seulensis larvae fermented by Bacillus subtilis improves the non-alcoholic fatty liver and can be used as an effective health food material for enhancing liver function.
\end{abstract}

Key words : fatty acid, edible insect, fermentation, larvae, Protaetia brevitarsis seulensis

\section{서 론}

간장은 지질 대사가 주로 이루어지는 곳으로, 간 무게의 $5 \%$ 이상의 지방이 과도하게 축적된 경우 지방간이라 한다. 지방간은 요인에 따라 크게 두 가지로 나뉘는데, 과량의 알코올 섭취로 인한 알코올성 지방간과 대사증후군 및 비 만, 당뇨 등에 의해서 생기는 비알코올성 지방간이 있다. 한편, 비알코올성 지방간은 음주 경력이 없는 사람에게서

*Corresponding author. E-mail : choys@dau.ac.kr Phone : 82-51-200-7586, Fax : 82-51-200-7505

Received 07 August 2019; Revised 20 August 2019; Accepted 30 August 2019.

Copyright (c) The Korean Society of Food Preservation. All rights reserved.
알코올성 지방간과 유사한 병리학적 소견을 보이는데, 비 만, 제 2형 당뇨병, 이상지질혈증, 대사증후군 등의 원인으 로 간 세포 내에 지방이 축적되면서 지방대사 및 합성의 불균형을 초래한다고 보고된다(1). 운동부족, 식생활의 서 구화 등의 요인에 의해 성인 당뇨 및 비만 환자 수가 증가함 에 따라, 이와 연관된 비알코올성 지방간 질환자 역시 늘고 있다. 국내에서도 과체중이나 비만, 고지혈증 등 대사성 질환을 가지는 인구가 과거에 비해 절대적으로 증가한다고 보고되고 있으며, 약물성 간 질환과 더불어 대사성 질환에 의한 간 손상의 중요성이 대두되고 있다(2)

최근 식량문제의 심각성이 대두됨에 따라 식량을 소재로 하는 연구가 활발히 진행되고 있는 추세다. 새로운 식량자 원으로 식 · 약용 곤충이 각광 받고 있으며, 우수한 영양학 적 가치에 관한 연구가 많이 진행되고 있다. 현재, 국내에서 
식용, 약용으로 사용되는 곤충으로는 누에, 번데기, 메뚜기, 갈색 거저리 외에 식품의약품안전처로부터 새로운 식품원 료로 굼벵이가 등록되어 식품 소재로 많이 활용되고 있다. 그 중에 흰점박이꽃무지 유충(굼벵이)은 항산화력(3)뿐만 아니라 간 기능 개선 효과가 있다고 알려져 있으며(4), 약리 학적 효과가 있어 약으로 쓰이는 등 기능적인 건강식품으로 도 유용하게 사용된다(5). 오늘날 소비자들은 친환경 제품 을 선호하며, 그 영향으로 발효 산업 역시 성장하고 있는 추세다. 유산균, 세균, 효모 및 곰팡이 등 유용미생물을 이용 한 발효 기술을 통해 알려진 기존 효능에서 새로운 생리 활성 부여할 뿐만 아니라 여러 가지 유용 성분증가(6) 등 다양한 이점을 부각시키는 연구가 활발히 진행 중이다.

따라서, 본 연구진은 선행연구로 유용미생물 중 하나인 Bacillus subtilis를 이용해 흰점박이꽃무지 유충(굼벵이)을 발효함으로써 항산화를 포함한 우수한 생리활성 작용을 확인하였고, 본 연구에서는 발효 굼벵이 분말을 orotic acid 에 의해 유발된 비알코올성 지방간 동물모델에 식이로 급여 함으로써 긍정적인 영향을 검토하고자 한다.

\section{재료 및 방법}

\section{실험재료, 발효 조건 및 식이조성}

본 연구에서 실험 재료로 사용한 건조 굼벵이는 2017년 6월 경상북도 경주 토종 마을(Gyeonju, Gyeongbuk)에서 구 입하여 사용하였다. 발효 균주로는 본 연구실 내 보관 중인 균주로, Bacillus subtilis KACC 91157(B. subtilis)을 사용하 였다. 본 연구에서 사용된 B. subtilis는 토양시료로부터 높 은 활성의 protease를 생산하는 세균이다. $5 \%(\mathrm{w} / \mathrm{w})$ 대두 천연배지에 전 배양 시킨 B. subtilis는 $3,000 \mathrm{rpm}$ 에 $15 \mathrm{~min}$ 동 안 원심 분리를 하여 균체만 회수하였다. 본 연구진의 선행 연구 결과(7)에 따라, 회수한 균체 중 $10 \%(\mathrm{v} / \mathrm{w})$ 수준의 균체만 멸균수에 희석하여 건조 굼벵이 분말에 잘 섞은 후 $37^{\circ} \mathrm{C}$ 에서 3 일간 고상 발효하였다. 3 일간의 발효 과정 중간에 발효물의 건조를 막기 위해 멸균수로 촉촉하게 버무 려 주었으며, 발효 후 $50^{\circ} \mathrm{C}$ 에서 5 시간 열풍 건조한 후 분말 화하여 식이로 사용하였다. 식이조성은 Table 2와 같으며, orotic acid와 타 영양성분을 혼합하여 대조구로 사용하였 고, Table 1과 같은 조건으로 굼벵이 분말 및 발효 굼벵이 분말을 농도 별로 나누어 경구 투여하였다.

\section{실험동물 및 사육조건}

실험동물은 6주령 Sprague-Dawley계 수컷 흰쥐를 효창 사이언스(Daegu, Korea)로부터 구입하였다. 본 실험에 사 용한 흰쥐를 체중이 동일하게 난괴법으로 분류하였으며, 각 실험군당 6-8마리씩 나누어 온도 $\left(22 \pm 2^{\circ} \mathrm{C}\right)$ 와 습도 $(50 \pm 5 \%)$ 및 명암주기 12시간(07:00-19:00)가 조절되는 동
물 사육실에서 사육하였다. 일주일간 시판 고형사료를 급 여하면서 환경에 적응시킨 후 본 실험에 사용하였으며, 사 육 기간 중 식이 섭취량은 매일 측정하였고, 체중은 3 일을 주기로 일정한 측정하였다. 동물 사육 및 실험동물 사용에 대한 국립 보건 연구소의 지침에 따랐다. 본 연구는 동아대 학교 동물실험 윤리심의 위원회의 승인(DIACUC-17-23)을 받아 진행하였다.

Table 1. Experimental design

\begin{tabular}{cc}
\hline Group & Composition \\
\hline $\mathrm{N}^{1)}$ & Normal \\
$\mathrm{C}^{2)}$ & Normal + Orotic acid (NO) \\
$\mathrm{NPb}^{3)}$ & $\mathrm{NO}+\mathrm{NPb} 100 \mathrm{mg} / \mathrm{kg}$ of b.w./day \\
$\mathrm{FPb}^{4} 10$ & $\mathrm{NO}+\mathrm{FPb} 10 \mathrm{mg} / \mathrm{kg}$ of b.w./day \\
$\mathrm{FPb} 100$ & $\mathrm{NO}+\mathrm{FPb} 100 \mathrm{mg} / \mathrm{kg}$ of b.w./day \\
$\mathrm{FPb} 200$ & $\mathrm{NO}+\mathrm{FPb} 200 \mathrm{mg} / \mathrm{kg}$ of b.w./day \\
\hline
\end{tabular}

\section{${ }^{1)} \mathrm{N}$, Normal.}

${ }^{2)} \mathrm{C}$, Control.

${ }^{3)} \mathrm{NPb}$, Non-fermented, Protaetia brevitarsis seulensis larvae.

${ }^{4} \mathrm{FPb}$, Protaetia brevitarsis seulensis larvae fermented by Bacillus subtilis for 3 days.

\section{시료 채취 및 분석시료 조제}

동물실험은 10 일간 각 조제 식이를 급여하면서 사육한 후, 실험 최종일에 12 시간 절식시키고, 디에텔에테르로 질 식시켜 해부하였다. 개복 후 복부 대동맥으로부터 채혈하 여 혈액을 채취하였고, 실온에서 약 $30 \mathrm{~min}$ 간 방치시킨 후 3,000 rpm에서 $20 \mathrm{~min}$ 간 원심분리 하여 얻은 혈청은 생화학적 분석에 제공되었다. 채혈 후 적출한 각 조직은 $0.9 \%$ 생리식염수로 세척하고, 여과지로 물기 제거 한 후 무게를 측정하고 냉동 보관하였다.

\section{혈청 지질농도 분석}

혈청 중 total lipid, total cholesterol, HDL-cholesterol, LDL-cholesterol, free fatty acid, phospholipid 및 triglyceride 활성은 의료 전문 수탁 검사기관인 (주동남의화학연구소 (Busan, Korea)와 (재)서울의과학연구소(Yongin, Gyeonggi$\mathrm{do})$ 에서 분석 진행하였으며, 간 조직의 병리 조직학적 관찰 은 록원바이오융합연구재단(Seoul, Korea)을 통해서 분석 하였다.

\section{간 조직의 병리조직학적 관찰}

해부 직후 적출한 간을 냉각 생리식염수로 관류하여 혈 액을 제거시킨 상태에서 조직의 일정한 부위의 일부분을 취하여 $10 \%$ 중성포르말린 용액에 고정시켜 파라핀 포매 과정을 거쳐 3-4um의 두께로 절편하여 hematoxylin and $\operatorname{eosin}(\mathrm{H} \& \mathrm{E})$ 염색한 후 광학현미경(Olympus BX41, Olympus Co., Tokyo, Japan)으로 관찰하였다. 


\section{통계처리}

실험으로부터 얻어진 결과는 one-way ANOVA 검정에 의한 평균치와 표준 오차 $(\mathrm{mean} \pm \mathrm{SE})$ 로 표시하였고, 각 실험 군 간의 유의성 검증은 Duncan's multiple range test로 나타 내었다(8).

\section{Table 2. Compositions of experimental diets}

\begin{tabular}{ccc}
\hline Ingredients & Normal & Fatty liver induced by orotic acid \\
\hline Casein & 20.0 & 20.0 \\
Corn starch & 15.0 & 14.0 \\
Corn oil & 10.0 & 10.0 \\
Cellulose & 5.0 & 5.0 \\
Mineral mixture ${ }^{1)}$ & 4.0 & 4.0 \\
Vitamin mixture $^{2)}$ & 1.0 & 1.0 \\
L-Methionine & 0.3 & 0.3 \\
Sucrose & 44.5 & 44.5 \\
Choline & 0.2 & 0.2 \\
Orotic acid & - & 1.0 \\
\hline Total & 100 & 100
\end{tabular}

${ }^{1)}$ AIN 93 M-MX mineral mix, MP biomedicals, Illkirch, France.

${ }^{2}$ AIN 93 VX vitamin mix, MP biomedicals, Illkirch, France.

${ }^{3)}$ Fatty liver induced by orotic acid: Diet for $\mathrm{C}, \mathrm{NPb}$ and $\mathrm{FPb}$.

\section{결과 및 고찰}

\section{체중, 식이 및 음료 섭취량 변화}

식이에 orotic acid $1 \%$ 수준으로 첨가하여 비알코올성 지방간을 유발한 흰쥐에 굼벵이 분말을 B. subtilis를 이용하 여 발효한 발효 굼벵이 분말이 미치는 영향을 확인하기 위해 10 일간 경구 투여하였다. 정상군(N군)의 체중 증가에 비해 orotic acid만 급여한 대조군(C군)의 체중 증가율는 감소된 경향을 보였다. 한편, 굼벵이 분말과 B. subtilis 균주 의 혼합물을 투여한 $\mathrm{NPb}$ 군(비발효군) 및 발효 굼벵이 분말 을 투여한 $\mathrm{FPb}$ 군(발효군)에서 체중 증가율이 전반적으로 증가하는 경향을 보였으며, 그 중에서도 $\mathrm{FPb} 100$ 군에서 높 은 체중 증가량을 보였다. 이는 식이를 급여함으로써 체내 독성을 완화시킨 것으로, orotic acid가 성장에 악영향을 미쳤으나, 발효 굼벵이 분말이 완화시킨 것이라고 사료된 다. 식이 및 음료 섭취량은 유의적인 특징을 나타나지 않았 다(Table 3).

\section{장기의 무게}

각 장기의 체중에 대한 절대적 중량 $(\mathrm{g})$ 및 상대적 중량 $(\%)$ 를 Table 4 와 5에 나타내었다. 간장의 무게는 N군과 비교하 여 orotic acid를 급여한 군에서 모두 증가하여, Cha 등(9)
연구에서 orotic acid군에서 간장의 무게가 증가한다는 결과 와 일치하였다. Microsomal triglyceride transfer protein (MTP)는 간세포와 소장 세포에 존재하는 단백질로 간장에 서 혈중으로 지질수송하는 VLDL에 관여하는 것으로 보고 된다(10). Orotic acid로 인해 MTP 활성이 저해됨으로서 간장 내 지질이 축적되어 체중은 감소할지라도 간장의 무게 는 증가한 것으로 사료된다. $\mathrm{NPb}$ 군과 $\mathrm{FPb}$ 군의 간장 무게는 $\mathrm{C}$ 군 $4.73 \%$ 에 비해 평균 $4.3 \%$ 유의적으로 감소한 결과를 보여, 굼벵이 분말 및 발효 굼벵이 분말의 투여가 지질 축적 으로 인한 지방간 비대 현상을 억제 시키는 영향을 준 것으 로 사료된다. 한편, 비장, 신장 및 고환의 무게는 모든 군에 서 유의적인 차이가 없었다. 신장주위지방의 무게는 N군에 비해 orotic acid를 급여한 군에서 모두 증가하였으며, 그 중에서도 굼벵이 분말을 투여한 $\mathrm{NPb}$ 군보다는 발효 굼벵이 분말을 투여한 $\mathrm{FPb}$ 군에서 유의적으로 낮아지는 결과를 보 였다. 특히, 발효 굼벵이 분말 농도가 높아질수록 신장지방 의 수치는 낮아진 것을 확인하였다. 고환주위지방의 무게 또한, 발효 굼벵이 분말을 투여한 군에서 대체적으로 낮아 지는 결과를 보였다.

\section{간장 및 혈중 중성지질 농도}

간장 내 중성지질은 활면 소포체에서 VLDL 입자가 만들 어지고 골지체로 이동해 성숙된 VLDL 입자가 MTP에 의해 혈중으로 분비된다(11). Orotic acid 과잉 투여시 간장에 중 성지질이 축적되어 지방간을 유발시킨다고 보고된다(12). 이는 간장에서 orotic acid가 MTP 활성과 전사를 억제 시켜 혈중으로의 지질 분비를 저해함으로써 간장에는 중성지질 이 축적되고, 반대로 혈중으로의 지질분비가 저해되는 것 을 알 수 있다. 간장 및 혈중 중성 지질 농도는 Fig. 1에 나타내었다. 간장 내 중성지질 농도변화 결과, $\mathrm{C}$ 군에서 현 저히 높은 수치를 확인할 수 있었고, 반대로 혈중 중성지질 농도에서는 $\mathrm{C}$ 군을 포함한 orotic acid 투여군에서 전체적으 로 낮은 중성지질 농도를 확인할 수 있었다. 따라서, 간장 내 중성지질은 높은 수치를 보인 것에 반해, 혈중 중성 지질 농도는 낮아진 것을 확인함으로써, 비알코올성 지방간이 유발됨을 확인할 수 있다. 굼벵이 분말 및 발효 굼벵이 분말 을 투여한 군에서 $\mathrm{C}$ 군과 비교하여 낮아진 수치를 보였고, 특히 발효 굼벵이 분말을 $100 \mathrm{mg} / \mathrm{kg}$ 및 $200 \mathrm{mg} / \mathrm{kg}$ 농도로 투여한 군에서 정상군의 중성지질 농도 수준으로 낮은 수치 를 나타내어 간장 내 중성지질 축적을 억제한 것으로 생각 된다. 또한, 발효 굼벵이 분말을 투여한 군에서 혈중 중성지 질함량이 증가함을 확인할 수 있는데, 이는 간장 내 중성지 질 축적을 저해함으로써 혈중으로 중성 지질이 방출되어 높은 수치를 나타낸 것으로 사료된다(13).

\section{혈청 중의 지질 농도 변화}

혈청 중의 지질농도 변화는 total lipid, free fatty acid 및 
Table 3. Change in body weight gain and water consumption in orotic acid-induced fatty liver model rats

\begin{tabular}{cccccc}
\hline & Initial weight $(\mathrm{g})$ & Final weight $(\mathrm{g})$ & Body weight gain $(\mathrm{g})$ & Food intake (g/day) & Water consumption (mL/day) \\
\hline $\mathrm{N}^{1)}$ & $203.13 \pm 5.46^{5) \mathrm{ab}}$ & $246.63 \pm 6.55^{\mathrm{a}}$ & $43.50 \pm 11.05^{\mathrm{a}}$ & $18.83 \pm 2.25^{\mathrm{a}}$ & $30.75 \pm 11.03^{\mathrm{a}}$ \\
$\mathrm{C}^{2)}$ & $205.25 \pm 7.52^{\mathrm{a}}$ & $241.25 \pm 12.60^{\mathrm{b}}$ & $36.00 \pm 15.04^{\mathrm{b}}$ & $19.68 \pm 0.37^{\mathrm{a}}$ & $30.21 \pm 11.78^{\mathrm{a}}$ \\
$\mathrm{NPb}^{3)}$ & $204.50 \pm 6.47^{\mathrm{a}}$ & $251.00 \pm 5.69^{\mathrm{bc}}$ & $46.50 \pm 8.29^{\mathrm{bc}}$ & $19.70 \pm 0.65^{\mathrm{a}}$ & $30.83 \pm 12.42^{\mathrm{a}}$ \\
$\mathrm{FPb}^{4} 10$ & $199.67 \pm 11.48^{\mathrm{a}}$ & $241.83 \pm 11.48^{\mathrm{ac}}$ & $42.17 \pm 4.49^{\mathrm{c}}$ & $18.33 \pm 1.72^{\mathrm{a}}$ & $29.44 \pm 10.87^{\mathrm{a}}$ \\
$\mathrm{FPb} 100$ & $202.67 \pm 3.01^{\mathrm{a}}$ & $250.17 \pm 2.86^{\mathrm{bc}}$ & $47.50 \pm 5.09^{\mathrm{bc}}$ & $19.73 \pm 0.37^{\mathrm{a}}$ & $37.78 \pm 14.51^{\mathrm{a}}$ \\
$\mathrm{FPb} 200$ & $204.67 \pm 3.14^{\mathrm{a}}$ & $249.17 \pm 7.91^{\mathrm{bc}}$ & $44.50 \pm 8.41^{\mathrm{c}}$ & $18.80 \pm 1.22^{\mathrm{a}}$ & $30.89 \pm 9.44^{\mathrm{a}}$ \\
\hline
\end{tabular}

${ }^{1)} \mathrm{N}$, Normal; ${ }^{2} \mathrm{C}$, Control; ${ }^{3)} \mathrm{NPb}$, Non-fermented, Protaetia brevitarsis seulensis larvae; ${ }^{4} \mathrm{FPb}$, Protaetia brevitarsis seulensis larvae fermented by Bacillus subtilis for 3 days. ${ }^{5}$ Values are mean \pm S.E $(\mathrm{n}=6)$.

${ }^{6 \mathrm{a}-\mathrm{c}}$ Values with different letters are significantly different at $\mathrm{p}<0.05$

Table 4. Absolute weight of tissues absolute weight in orotic acid-induced fatty liver model rats (g)

\begin{tabular}{|c|c|c|c|c|c|c|c|}
\hline & Liver & Heart & Spleen & Kindey & Testis & Perimental fat Pad & Epididymal fat Pad \\
\hline $\mathrm{N}^{1)}$ & $8.60 \pm 0.60^{5 \mathrm{a} a)}$ & $1.04 \pm 0.08^{\mathrm{a}}$ & $0.52 \pm 0.11^{\mathrm{a}}$ & $2.05 \pm 0.09^{\mathrm{a}}$ & $2.91 \pm 0.21^{\mathrm{a}}$ & $2.45 \pm 0.65^{\mathrm{a}}$ & $3.23 \pm 0.65^{\mathrm{a}}$ \\
\hline$C^{2)}$ & $11.64 \pm 1.74^{\mathrm{b}}$ & $1.10 \pm 0.12^{\mathrm{a}}$ & $0.62 \pm 0.04^{\mathrm{a}}$ & $2.26 \pm 0.13^{b}$ & $2.87 \pm 0.12^{\mathrm{a}}$ & $3.20 \pm 0.25^{\mathrm{b}}$ & $3.51 \pm 0.85^{\mathrm{a}}$ \\
\hline $\mathrm{NPb}^{3)}$ & $10.63 \pm 1.03^{\mathrm{bc}}$ & $0.95 \pm 0.22^{\mathrm{a}}$ & $0.56 \pm 0.12^{\mathrm{a}}$ & $2.32 \pm 0.07^{\mathrm{b}}$ & $2.95 \pm 0.16^{\mathrm{a}}$ & $3.12 \pm 0.38^{\mathrm{b}}$ & $3.40 \pm 0.51^{\mathrm{a}}$ \\
\hline $\mathrm{FPb}^{4} 10$ & $11.09 \pm 1.36^{\mathrm{bc}}$ & $1.03 \pm 0.11^{\mathrm{a}}$ & $0.57 \pm 0.09^{\mathrm{a}}$ & $2.22 \pm 0.07^{\mathrm{b}}$ & $2.81 \pm 0.19^{\mathrm{a}}$ & $2.85 \pm 0.57^{\mathrm{ab}}$ & $2.80 \pm 0.90^{\mathrm{a}}$ \\
\hline $\mathrm{FPb} 100$ & $11.02 \pm 0.76^{\mathrm{bc}}$ & $1.06 \pm 0.08^{\mathrm{a}}$ & $0.63 \pm 0.07^{\mathrm{a}}$ & $2.23 \pm 0.04^{\mathrm{b}}$ & $2.97 \pm 0.15^{\mathrm{a}}$ & $2.72 \pm 0.51^{\mathrm{ab}}$ & $2.58 \pm 0.70^{\mathrm{a}}$ \\
\hline $\mathrm{FPb} 200$ & $10.11 \pm 0.80^{c}$ & $1.02 \pm 0.05^{\mathrm{a}}$ & $0.60 \pm 0.08^{\mathrm{a}}$ & $2.22 \pm 0.11^{\mathrm{b}}$ & $2.83 \pm 0.10^{\mathrm{a}}$ & $2.62 \pm 0.32^{\mathrm{ab}}$ & $2.78 \pm 0.76^{\mathrm{a}}$ \\
\hline
\end{tabular}

${ }^{11} \mathrm{~N}$, Normal; ${ }^{2} \mathrm{C}$, Control; ${ }^{3} \mathrm{NPb}$, Non-fermented, Protaetia brevitarsis seulensis larvae; ${ }^{4} \mathrm{FPb}$, Protaetia brevitarsis seulensis larvae fermented by Bacillus subtilis for 3 days. ${ }^{5}$ Values are mean \pm S.E $(\mathrm{n}=6)$.

${ }^{6) \mathrm{a}-\mathrm{C}}$ Values with different letters are significantly different at $\mathrm{p}<0.05$.

Table 5. Relative weight of tissues relative weight in orotic acid-induced fatty liver model rats (\% of terminal body weight)

\begin{tabular}{cccccccc}
\hline & Liver & Heart & Spleen & Kindey & Testis & Perimental fat Pad & Epididymal fat Pad \\
\hline $\mathrm{N}^{1)}$ & $3.51 \pm 0.24^{5 / 2 a}$ & $0.42 \pm 0.04^{\mathrm{a}}$ & $0.21 \pm 0.04^{\mathrm{a}}$ & $0.84 \pm 0.05^{\mathrm{a}}$ & $1.19 \pm 0.08^{\mathrm{a}}$ & $1.00 \pm 0.27^{\mathrm{a}}$ & $1.32 \pm 0.28^{\mathrm{a}}$ \\
$\mathrm{C}^{2)}$ & $4.73 \pm 0.77^{\mathrm{b}}$ & $0.45 \pm 0.05^{\mathrm{a}}$ & $0.25 \pm 0.02^{\mathrm{a}}$ & $0.92 \pm 0.04^{\mathrm{b}}$ & $1.17 \pm 0.05^{\mathrm{a}}$ & $1.30 \pm 0.13^{\mathrm{b}}$ & $1.43 \pm 0.36^{\mathrm{a}}$ \\
$\mathrm{NPb}^{3)}$ & $4.23 \pm 0.41^{\mathrm{bc}}$ & $0.38 \pm 0.09^{\mathrm{a}}$ & $0.22 \pm 0.04^{\mathrm{a}}$ & $0.92 \pm 0.04^{\mathrm{b}}$ & $1.17 \pm 0.07^{\mathrm{a}}$ & $1.24 \pm 0.14^{\mathrm{ab}}$ & $1.36 \pm 0.23^{\mathrm{a}}$ \\
$\mathrm{FPb}^{4} 10$ & $4.58 \pm 0.51^{\mathrm{bc}}$ & $0.42 \pm 0.04^{\mathrm{a}}$ & $0.23 \pm 0.03^{\mathrm{a}}$ & $0.92 \pm 0.03^{\mathrm{b}}$ & $1.16 \pm 0.08^{\mathrm{a}}$ & $1.18 \pm 0.25^{\mathrm{ab}}$ & $1.16 \pm 0.36^{\mathrm{a}}$ \\
$\mathrm{FPb}^{\mathrm{b}} 00$ & $4.41 \pm 0.32^{\mathrm{bc}}$ & $0.42 \pm 0.03^{\mathrm{a}}$ & $0.25 \pm 0.03^{\mathrm{a}}$ & $0.89 \pm 0.02^{\mathrm{b}}$ & $1.19 \pm 0.05^{\mathrm{a}}$ & $1.09 \pm 0.21^{\mathrm{ab}}$ & $1.03 \pm 0.29^{\mathrm{a}}$ \\
$\mathrm{FPb} 200$ & $4.05 \pm 0.21^{\mathrm{c}}$ & $0.41 \pm 0.03^{\mathrm{a}}$ & $0.24 \pm 0.04^{\mathrm{a}}$ & $0.89 \pm 0.03^{\mathrm{b}}$ & $1.14 \pm 0.07^{\mathrm{a}}$ & $1.05 \pm 0.13^{\mathrm{ab}}$ & $1.12 \pm 0.32^{\mathrm{a}}$ \\
\hline
\end{tabular}

${ }^{11} \mathrm{~N}$, Normal; ${ }^{2} \mathrm{C}$, Control; ${ }^{3} \mathrm{NPb}$, Non-fermented, Protaetia brevitarsis seulensis larvae; ${ }^{4} \mathrm{FPb}$, Protaetia brevitarsis seulensis larvae fermented by Bacillus subtilis for 3 days. ${ }^{5}$ Values are mean \pm S.E $(\mathrm{n}=6)$.

${ }^{6 \mathrm{a}-\mathrm{c}}$ Values with different letters are significantly different at $\mathrm{p}<0.05$.

phospholipid로 확인할 수 있으며, 그 함량은 Table 6에 나타내었다. 간 조직은 지질대사에 중요한 조직으로 여러 지질성분과 밀접한 관련성이 있다. Total lipid, free fatty acid 농도는 정상군에 비해 $\mathrm{C}$ 군에서 현저히 감소되었다. 이는, 간 조직에서 혈중으로 분비되는 지질 운반체 $\mathrm{VLDL}$ 의 분비 저하 때문인 것으로 판단된다(10). Total lipid의 경우, $\mathrm{C}$ 군에 비해 굼벵이 분말 및 발효 굼벵이 분말을 투여한 $\mathrm{FPb} 200$ 군을 제외한 모든 군에서 전반적으로 증가된 경향을 보였다. 또한, free fatty acid는 $\mathrm{NPb}$ 군 및 $\mathrm{FPb} 10$ 군에서는
큰 차이는 없었지만, 발효 굼벵이 분말을 고농도로 급여한 군에서는 정상군과 비슷한 높은 수치를 나타내었다. 한편, phospholipid의 농도 변화는 전체적으로 큰 차이는 나타나 지 않았지만, 발효 굼벵이 분말 $100 \mathrm{mg} / \mathrm{kg}$ 농도로 투여한 군에서 높은 함량을 나타내었다. 혈중 지질농도 변화를 확 인한 결과, 발효 굼벵이 분말을 투여함으로써 지방간 개선 에 긍정적인 영향이 미치는 것을 확인하였다.

지방간은 간 조직 내 지방이 정상보다 과다 축적되어 나타나는 질환으로, 지방간염, 간경변 등 다양한 형태의 

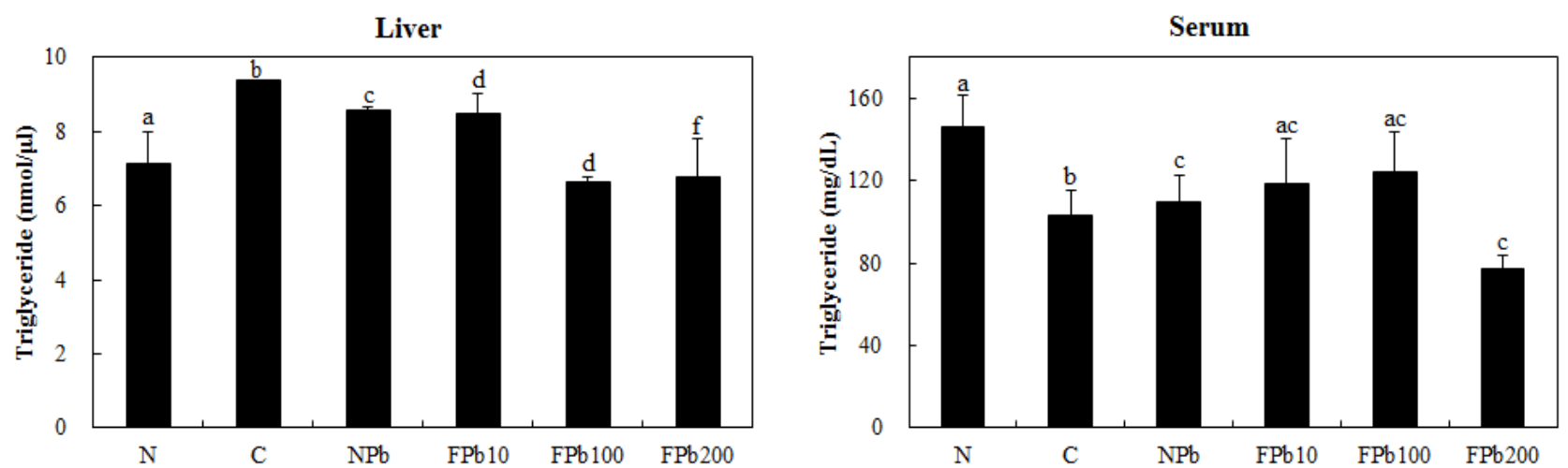

Fig. 1. Effect of $P$. brevitarsis seulensis larvae fermented by $B$. subtilis on the concentration of triglyceride in liver and serum in orotic acid-induced fatty liver model rats.

N, Normal; C, Control; NPb, Non-fermented, Protaetia brevitarsis seulensis larvae; FPb, Protaetia brevitarsis seulensis larvae fermented by Bacillus subtilis for 3 days. Values are mean $\pm \mathrm{S} . \mathrm{E}(\mathrm{n}=6) .{ }^{\mathrm{a}-\mathrm{V}}$ Values with different letters are significantly different at $\mathrm{p}<0.05$.

Table 6. Effects of $P$. brevitarsis seulensis larvae fermented by $B$. subtilis on the concentrations of total cholesterol, HDL cholesterol, LDL cholesterol, total lipid, free fatty acid and phospholipid in orotic acid-induced fatty liver model rats

\begin{tabular}{ccccccc}
\hline Group & Total cholesterol (mg/dL) HDL cholesterol (mg/dL) LDL cholesterol (mg/dL) & Total lipid (mg/dL) & Free fatty acid (uEq/L) & Phospholipid (mg/dL) \\
\hline $\mathrm{N}^{1)}$ & $75.68 \pm 3.26^{5 \mathrm{aa})}$ & $69.30 \pm 3.62^{\mathrm{a}}$ & $0.18 \pm 0.02^{\mathrm{a}}$ & $518.84 \pm 64.93^{\mathrm{a}}$ & $1066.38 \pm 136.57^{\mathrm{a}}$ & $148.63 \pm 17.23^{\mathrm{a}}$ \\
$\mathrm{C}^{2)}$ & $68.48 \pm 9.21^{\mathrm{bc}}$ & $62.77 \pm 4.79^{\mathrm{b}}$ & $0.37 \pm 0.09^{\mathrm{b}}$ & $450.61 \pm 66.74^{\mathrm{b}}$ & $498.38 \pm 123.09^{\mathrm{b}}$ & $154.00 \pm 30.08^{\mathrm{b}}$ \\
$\mathrm{NPb}^{3)}$ & $72.48 \pm 4.37^{\mathrm{ac}}$ & $71.41 \pm 3.49^{\mathrm{ac}}$ & $0.31 \pm 0.05^{\mathrm{b}}$ & $481.87 \pm 28.71^{\mathrm{ab}}$ & $485.67 \pm 144.60^{\mathrm{b}}$ & $154.17 \pm 9.54^{\mathrm{a}}$ \\
$\mathrm{FPb}^{4} 10$ & $79.18 \pm 4.68^{\mathrm{a}}$ & $75.60 \pm 3.16^{\mathrm{ac}}$ & $0.31 \pm 0.06^{\mathrm{b}}$ & $476.90 \pm 30.52^{\mathrm{ab}}$ & $495.00 \pm 92.68^{\mathrm{b}}$ & $165.17 \pm 10.94^{\mathrm{a}}$ \\
$\mathrm{FPb}^{\mathrm{b}}$ & $79.21 \pm 4.62^{\mathrm{a}}$ & $76.35 \pm 8.01^{\mathrm{c}}$ & $0.30 \pm 0.07^{\mathrm{b}}$ & $468.33 \pm 35.51^{\mathrm{ab}}$ & $772.83 \pm 139.91^{\mathrm{c}}$ & $166.17 \pm 22.78^{\mathrm{a}}$ \\
$\mathrm{FPb} 200$ & $62.93 \pm 10.64^{\mathrm{b}}$ & $61.51 \pm 9.21^{\mathrm{b}}$ & $0.30 \pm 0.12^{\mathrm{b}}$ & $393.33 \pm 35.41^{\mathrm{c}}$ & $753.37 \pm 175.18^{\mathrm{c}}$ & $133.33 \pm 14.71^{\mathrm{b}}$ \\
\hline
\end{tabular}

${ }^{1)} \mathrm{N}$, Normal; ${ }^{2} \mathrm{C}$, Control; ${ }^{3} \mathrm{NPb}$, Non-fermented, Protaetia brevitarsis seulensis larvae; ${ }^{4} \mathrm{FPb}$, Protaetia brevitarsis seulensis larvae fermented by Bacillus subtilis for 3 days.

${ }^{5}$ Values are mean \pm S.E $(\mathrm{n}=6)$.

${ }^{6)-c}$ Values with different letters are significantly different at $\mathrm{p}<0.05$.

질병을 초래한다. 콜레스테롤은 세포의 원형질막 및 혈중 지질단백의 구성성분으로 알려져 있으며, 간에서 합성 및 조절된다고 보고된다(14). 한편, orotic acid를 과량 섭취하 게 될 시 나타나는 문제로는, 간 조직에서 혈중으로 분비되 는 지질 운반체 $\mathrm{VLDL}$ 의 분비 저하로 인해 저지혈증이 대표 적이다(15).혈중 총 콜레스테롤 농도는, C군에서 낮은 수치 를 나타내었고, 굼벵이 분말과 발효 굼벵이 분말을 투여한 모든 군에서 정상군과 유사한 경향을 보였다. 그 중, 발효 굼벵이 분말을 $10 \mathrm{mg} / \mathrm{kg}$ 및 $100 \mathrm{mg} / \mathrm{kg}$ 농도로 급여한 군에 서 높은 수치를 내었으나, $200 \mathrm{mg} / \mathrm{kg}$ 농도에서는 오히려 낮아진 경향을 확인할 수 있었다. 이는 간장 내 중성지질 축적이 됨으로써 혈중 내 지질함량이 낮아진 것으로 사료된 다. 풍뎅이 유충인 굼벵이 중에서 장수풍뎅이 유충 추출물 처리농도가 증가함에 따라 세포독성이 농도 의존적으로 증가하는 결과와 유사하게 본 연구에서 소재로 사용된 굼벵 이 중 흰점박이꽃무지 유충을 이용한 발효물에서도 비슷한 결과가 도출된 것으로 판단된다(16).

혈청의 HDL-cholesterol의 농도는 C군에 비해 굼벵이 분
말 및 발효 굼벵이 분말을 투여한 군에서 대체적으로 증가 된 양상을 보였고, 앞선 연구결과와 유사하게 발효 굼벵이 분말을 $10 \mathrm{mg} / \mathrm{kg}, 100 \mathrm{mg} / \mathrm{kg}$ 농도로 투여한 군에서 높은 수치를 나타내었으나, 고농도의 발효 굼벵이 분말을 급여 한 군에서는 오히려 낮아진 농도를 확인할 수 있었다. HDL-cholesterol가 감소하게 되면 고혈압 및 동맥경화증과 같은 심혈관계 질환을 유발하고, LDL-cholesterol 및 중성지 방이 증가하여 고지혈증의 주요인자로 보고된다(17). LDL-cholesterol은 정상군에 비해 orotic acid를 투여한 모든 군에서 증가된 수치를 나타내었고, 굼벵이 분말 및 발효 굼벵이 분말을 투여함으로써 감소된 경향을 보였다. Kang 등(4) 연구에서도, 알코올 투여가 총 콜레스테롤과 LDL-cholesterol의 증가를 초래하여 성인성 질환 중의 하나 인 관상심장 질환의 유발에 기여할 수 있을 것으로 보고되 었다. 또한, 굼벵이를 투여한 동물실험에서 동맥경화지수 를 약 $36 \%$ 정도 감소시켜 본 연구와 유사한 결과를 토대로 비알코올성 지방간에서도 굼벵이의 투여에 의해 감소되는 연구 결과를 확인하였다(18). 


\section{간 조직의 병리조직학적 관찰}

실험동물을 해부한 직후 간 조직을 적출하여 $\mathrm{H \& E}$ 염색 을 통해 병리학적 검사를 실시한 결과, $\mathrm{N}$ 군에서는 간 소엽 구조가 잘 유지되어 있었고,간세포들은 둥근 핵을 가지고, 균일하게 배열되어 있는 형상을 보였다(Fig. 2). C군은 간세 포 내 지방구의 증가로 지방간의 유발됨을 확인하였고, $\mathrm{NPb}$ 군 및 $\mathrm{FPb}$ 군에서 지방구의 수가 줄어드는 경향을 보였 다. 특히, $\mathrm{FPb} 100$ 군 및 $\mathrm{FPb} 200$ 군에서 간 소엽 구조가 잘
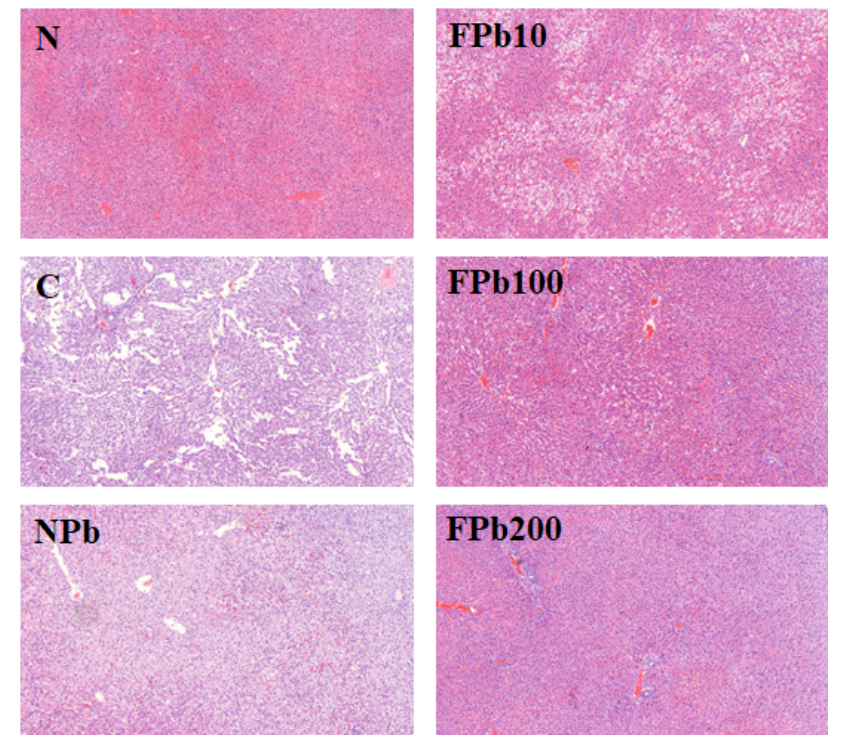

Fig. 2. Effect of $P$. brevitarsis seulensis larvae fermented using $B$. subtilis on the hepatic histopathologic changes in orotic acid-induced fatty liver model rats(magnification x 50). Hepatocyte staining was carried out with the hematoxylin and eosin staining method.
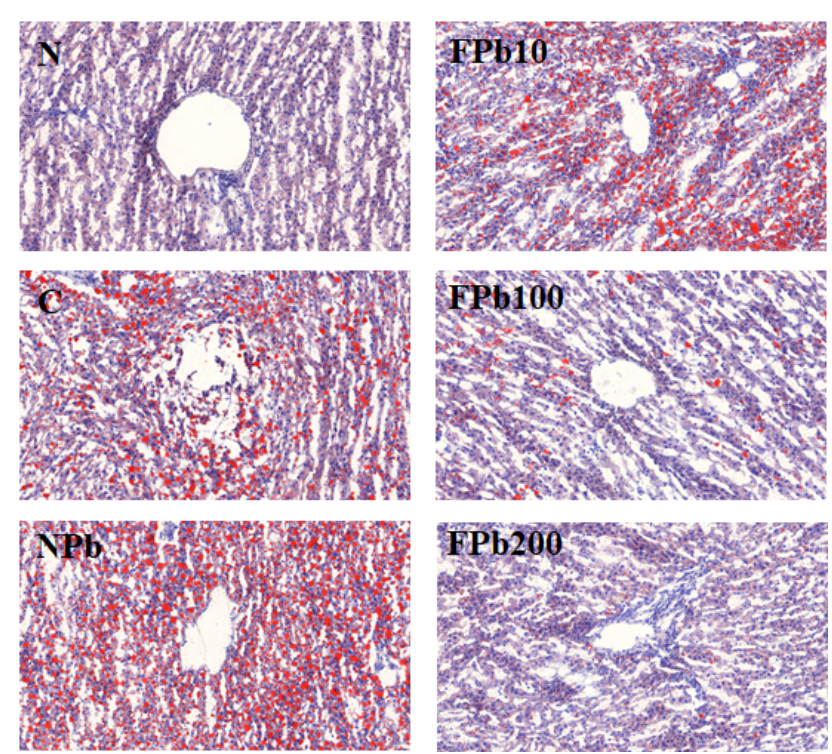

Fig. 3. Effect of $P$. brevitarsis seulensis larvae fermented using $B$. subtilis on the histological images of adipocytes in liver in orotic acid-induced fatty liver model rats (Oil red $O$ stain, $x$ 100).
유지 되어 있고, 지방구가 줄어드는 등 지방간 개선효과가 있는 것으로 판단되었다. Oil red O 염색을 통해 혈관 벽 주위를 확인 결과, $\mathrm{N}$ 군에 비해 $\mathrm{C}$ 군의 혈관 벽이 크게 무너 져 있는 것을 확인 할 수 있었다. $\mathrm{NPb}$ 군 및 $\mathrm{FPb}$ 군도 $\mathrm{C}$ 군에 비해 간 소엽을 구성하고 있는 간 세포들이 전반적으로 균일하게 배열되어 있었고, 그 중에서도 $\mathrm{FPb} 100$ 군이 N군 과 비슷한 소견을 보여 지방간 개선 효과가 있는 것으로 나타났다(Fig. 3).

이상의 결과로, B. subtilis 균주로 발효시킨 굼벵이 분말 을 orotic acid로 유발한 지방간 동물모델에서 간 조직에 지방이 축적되는 것을 억제하는 효과가 있다고 판단되며, 그 결과 지방간의 개선이 이루어졌다고 사료된다.

\section{요 약}

본 연구는 B. subtilis를 이용하여 발효한 굼벵이 분말이 orotic acid에 의해 지방간이 유발된 동물모델 내 지방간 개선 효과를 검토하였다. 발효 굼벵이 분말은 orotic acid 지방간 유발 실험동물의 간 조직 및 혈청 중성지질 농도를 낮춰주고, 반대로 혈청 지질농도는 정상 수준으로 올려주 어 지방간 개선에 도움을 주었다. 혈청 내의 total lipid와 free fatty acid 농도는 굼벵이 분말을 급여한 군보다 발효 굼벵이 분말을 투여한 군에서 수치가 감소하며 전반적으로 지질대사와 관련된 개선 효과를 나타내었다. 비슷한 양상 으로, HDL-cholesterol 함량은 orotic acid만 급여한 군에 비 해 굼벵이 분말 및 발효 굼벵이 분말을 투여한 군에서 정상 군의 수치와 비슷한 양상을 보였다. 한편, 발효 굼벵이 분말 을 고농도로 투여한 군에서는 오히려 세포 내 독성을 일으 킨 것으로 사료된다. 간 조직의 병리학적 관찰결과, 발효 굼벵이 분말을 투여한 $\mathrm{FPb}$ 군이 간 소엽을 구성하고 있는 간세포들이 전반적으로 균일하게 배열되어 있어 지방간의 개선 효과가 있는 것으로 보였다.

따라서, B. subtilis로 발효한 굼벵이 분말의 비알코올성 지방간 개선 효과에 대한 연구 결과, 비알코올성 지방간에 대해 긍정적인 효과를 나타내어 간 기능 개선에 효과적인 건강기능식품의 소재로써 활용할 가치가 높은 것으로 사료 된다.

\section{감사의 글}

본 결과물은 농림축산식품부의 재원으로 농립식품기술 기획평가원의 고부가가치식품기술개발사업(과제번호: 317039-4)의 지원을 받아 연구되었습니다. 


\section{References}

1. Moon KW, Leem JM, Bae SS, Lee KM, Kim SH, Chae HB, Park SM, Youn SJ (2004) The prevalence of metabolic syndrome in patients with nonalcoholic fatty liver disease. Korean J Hepatol, 10, 197-206

2. Lee JH, Kang KH, Kim SH, Park JH, Cho CM, Kwon YO, Kim SK, Choi YH (2005) The association of elevated alanine aminotransferase activity with obesity in health screening subjects. Korean J Med, 69, 46-54

3. Sim SY, Ahn HY, Seo KE, Cho YS (2018) Physicochemical properties and biological activities of Protaetia brevitarsis seulensis larvae fermented by several kinds of micro-organisms. J Life Sci, 28, 827-834

4. Kang IJ, Chung CK, Kim SJ, Nam SM, Oh SH (2001) Effects of Protaetia orientalis (Gory et Perchlon) larva on the lipid metabolism in carbon tetrachloride administered rats. Korean J Electron Microscopy, 31, 9-18

5. Kwak KW, Han MS, Nam SH, Choi JY, Lee SH, Choi YC, Park KH (2014) Detection of insect pathogen Serratia marcescens in Protaetia brevitarsis seulensis (Kolbe) from Korea. Int J Indust Entomol, 28, 25-31

6. Park SJ, Seong DH, Park DS, Kim SS, Gou JY, Ahn JH, Yoon WB, Lee HY (2009) Chemical compositions of fermented Codonopsis lanceolata. J Korean Soc Food Sci Nutr, 38, 396-400

7. Sim SY, Jang SH, Ahn HY, Cho HD, Seo KI, Cho YS (2019) Optimization of fermentation conditions Protaetia brevitarsis seulensis larvae using Bacillus subtilis. Korean J Food Preserv, 26, 123-133

8. Duncan DB (1959) Multiple range and multiple $F$ test. Biometrics, 11, 1-42

9. Cha JY, Mameda Y, Yamamoto K, Oogami K, Yanagita $\mathrm{T}$ (1998) Association between hepatic triacylglycerol accumulation induced by administering orotic acid and enhanced phosphatidate phosphohydrolase activity in rats. Biosci Biotechnol Biochem, 62, 508-513
10. Cha JY, Cho YS (2001) Effects of orotic acid and di-(2-ethylhexyl) phthalate on microsomal triglyceride transfer protein (MTP) activity and mRNA levels in liver and intestine of rats. Korean J Food Sci Technol, 33, 492-496

11. Ahn HY, Choe DJ, Cho YS (2015) Improvement effect of fermented Orostachys malacophyllus against orotic Acid-induced fatty liver model rats. J Life Sci, 25, 917-924

12. Cha JY, Cho YS, Kim I, Anno T, Rahman SM, Yanagita $\mathrm{T}$ (2001) Effect of hesperetin, a citrus flavonoid, on the liver triacylglycerol content and phosphatidate phosphohydrolase activity in orotic acid-fed rats. Plant Foods Hum Nutr, 56, 349-358

13. Song EJ, Cho KH, Choo HJ, Yang EY, Jung YK, Seo MG, Kim JC, Kang EJ, Gyu GH, Park BY, Hah YS (2017) Hepatoprotective effects of Semisulcospira libertine hydrolysate on alcohol-induced fatty liver in mice. Food Eng Prog, 21, 318-325

14. Song YB, Kyung JS, Park SB, Wee JJ, Do JH, Kim YS (2008) Influence of Korean red ginseng water extract on recovery of hepatic function in hypercholesterolemic mice fed high cholesterol diet. J Ginseng Res, 32, 283-290

15. Ahn HY, Park KR, Cho YS (2014) Effect of fermented Angelica gigas Nakai on lipid metabolism in orotic acid model rats. J Life Sci, 24, 743-749

16. Yoon WJ, Lee JA, Kim JY, Kim SB, Park SY (2007) Antioxidant activity and physiological function of the Anomala albopilosa extracts. J Korean Soc Food Sci Nutr, 36, 670-677

17. Jin GH, Lee TS (2018) Anti-hyperlipidemic effect of Agaricus brasiliensis fruiting bodies in rats fed with high cholesterol diet. J Mushroom, 16, 118-124

18. Kang IJ (2000) Effects of Protaetia orientalis (Gory et Perchlon) larva on the lipid metabolism in ethanol administered rats. J Korean Soc Food Sci Nutr, 29, 479-484 